\title{
Becoming refugee in Cairo: The political in performativity
}

Authors: Jouni Häkli, Elisa Pascucci, Kirsi Pauliina Kallio

\section{Introduction}

Global mobility continues to challenge and unsettle forms of citizenship, political engagement, and belonging in various ways. Within this voluminous and wide-ranging movement, it is particularly the figure of the 'refugee' that has come to question the "national order of things" (Malkki 1995). Paradoxically, refugees both disrupt this order by simply existing and depend on it to exist in the first place. The 1951 Refugee Convention defines a refugee as someone who "owing to well-founded fear of being persecuted for reasons of race, religion, nationality, membership of a particular social group or political opinion, is outside the country of his nationality and is unable or, owing to such fear, is unwilling to avail himself of the protection of that country" (UNHCR 2010,14).

This 'nationally ordered' definition of a refugee is deceptively simple. As the scholarship on forced migration has amply shown, the notion is highly contested not only academically and practically, but also politically (Soguk 1999; Moulin and Nyers 2007; Gill 2010; James 2014). Besides conceptual, legislative, and structural complexities, the trajectories by which people become refugees are far from settled or straightforward (Hamood 2006; Nyers 2006; YuvalDavis 2013; Hodge 2015). On the contrary, in contexts of forced displacement within the developing world, the United Nations High Commissioner for Refugees (UNHCR) only occasionally recognizes migrants as 'prima facie' refugees. This is the case typically with asylum seekers who come from certain conflict areas or belong to a group that has been subject to generalized violence. In most other cases, asylum seekers have to convince the aid agencies that they qualify for international protection.

In recent scholarship on experiences of seeking asylum and being a refugee it has become clear that the active seeking for refugee status, which most travelers have to accomplish to be formally helped, involves a subjective negotiation of experienced and performed identity that Liisa Malkki (1992) has referred to as 'refugeeness'. What she wanted to highlight was that being a refugee was not necessarily a negative or stigmatizing identity, but rather it could come to stand for "a sign of the ultimate temporariness of exile and of the refusal to become naturalized" (Malkki 1992, 35).

The subsequent scholarship on refugee subjectivities has provided several important conceptual avenues that deepen our understanding of the complexities that pertain to asylum seeking as an experience characterized by multiple liminalities and ambiguities. Much of this work has approached refugee subjectivities as subjectification, that is, as "a technology of government that works through the construction of certain forms of refugee subjectivities" (Olivius 2014, 43). Attention has been paid to the ways in which the 'refugee' is constructed as a subject position that asylum seekers have to adopt so as to 'fit in' with the policies providing them assistance and support. When internalized, the refugee subjectivity turns into a powerful force that subjugates those who fall within the remit of the international refugee regime (Lacroix 2004; Latif 2008). 
In what has become a dominant interpretation of this situation, the refugee subject is inscribed with voicelessness and dependence that create refugees as passive, victimized, and subordinate subjects (e.g. Ong 2003; Aberman 2014; Luker 2015). For some scholars this produces refugeeness as a gendered position that associates with infancy or femininity as negativity (e.g. Gass 2014), whereas others view it as a paradigmatic figure of Giorgio Agamben's (1998) 'bare life' embodying the permanent state of exception (Edkins 2000; Diken and Laustsen 2005; Darling 2009).

While we consider it important to critically assess the categorical misrecognition and subjugation that is at play in the negotiation of refugee subjectivities, we share the concern of authors such as Peter Nyers $(1998,2006)$, Nevzat Soguk (1999) and William Walters (2008) who have cautioned against viewing refugee subjectivities as preordained identity constructions imbued with powerlessness (see also Puumala and Pehkonen 2010; Darling 2014). To do so runs the risk of depriving asylum seekers of voice and emptying refugee subjects from the possibility of any political agency, thus reproducing the conception of "migrants as passive and helpless beings" (Walters 2008, 188). The limitations of such a perspective appear all the more evident in a time when, at a global level, migrant and refugee protests are becoming increasingly common not only in urban contexts but also in detention centres and refugee camps (Tyler and Marciniak 2013; Sanyal 2014; Ilcan and Rygiel 2015; Darling 2016)

In general we agree with these criticisms but in this article wish to recalibrate the discussion on refugee subjectivities on slightly different grounds related to the political resonances of subjectivity (Häkli and Kallio 2014; Kallio and Häkli 2017). Here it may be useful to notice that the usage of the concept has different emphases ranging from 'subjecthood' to 'subjection' whereby, in the first instance, subjectivity refers to how all human beings exist in the world and, in the second, to the powerful social and material forces that shape this being. Of course, these readings are interrelated, but we argue that attention to the political implications of the latter has greatly outweighed the former and therefore we lack a nuanced understanding of the empowering potential of refugee subjectivities (see also Owens 2012; Rossdale 2015).

It is in these terms that we set out to analyze refugee subjectivities related to 'becoming refugee'; not as a technology of governmentality, but rather as the condition of possibility to political agency based on the capacities of asylum seekers to become attentive to their positions and shared grievances, to raise awareness of inequalities and injustices, and ultimately, to mobilize individually and collectively (cf. Isin 2012). The paper is based on the analysis of interviews carried out with asylum seekers in January 2015 in Cairo, a city that hosts one of the biggest UNHCR operations in North-Africa and the Middle East. In discussing how those who are not entitled to 'prima facie' refugee status find themselves and perform as refugees in need of help from aid organizations, the paper leans on an experience-based understanding of political agency (Bayat 2010; McNay 2014; Baines 2015).

We begin by portraying the urban context of our research, introducing the contemporary situation of refugee movement in Cairo, and the UNHCR as the major actor of 'global refugee aid' in this context. After that, we present the idea of 'performing refugeeness' and our 
analytical starting points, and situate our contribution in the existing research. The third section introduces briefly our study and the analyzed materials. After that, we move into analysing the politics of performing refugeeness with focus on moments of attentiveness towards the figure of the refugee, a political subjectivity that may turn to awareness of injustices and lead to various kinds of political activities. In conclusion, we summarize briefly the results of the analysis and propose how they may be helpful in understanding political mobilization even in the most demanding and oppressive situations.

\section{Urban refugee policies: self-reliance and its contestation}

In June 2013, Gutama Gallato Bati, a thirty-three-year-old Ethiopian asylum seeker, spent around twenty days camping in front of the United Nations High Commissioner for Refugees (UNHCR) building in Cairo. Together with him over a hundred Ethiopian asylum seekers had responded to the call of the Oromo Sons Refugee Community Centre in Cairo, to gather for a protest against the UN office. They were asking the UNHCR to provide enhanced material and financial assistance to asylum seekers, and to work to find measures to protect them from the rising anti-African xenophobia. Protesters had set-up cardboard beds and makeshift kitchens, which implied that they were ready to spend days and nights at the sitin. To make this explicit, one of the protest leaders kept repeating to the many international and local reporters who visited the encampment that "we will not leave until the UNHCR will protect us". ${ }^{1}$

Gutama's story, which became world-known after Al Jazeera news made his case public, is representative of the conditions of many asylum seekers in Cairo. Having fled political persecution as a supporter of the Oromo Liberation Front in Ethiopia, he arrived in Cairo to apply for asylum, only to find himself living in extremely precarious conditions. Just a few days before joining the protests in Sixth of October, the Cairo suburb where the UNHCR offices are located, Gutama's Egyptian landlord had evicted him as the result of a dispute. Gutama attributed this to the wide-spread anti-Ethiopian feelings. In the heat of Cairo's summer, he found shelter in the Oromo encampment. Thus, he became one of the thousands of asylum seeker demonstrators in Egypt to have taken part in sit-ins and open protests.

Such refugee-initiated events are not detached from the more general struggles against the violent and exclusionary effects of the local system of governance in Cairo (Bush and Ayeb 2012; Achcar 2013). In those mobilizations, refugees had often been at the forefront. They had not only shared in the daily struggles for food, water, shelter, and against police violence that characterize the daily life in Cairo's deprived neighborhoods (Grabska 2006), but also taken actively part in overt collective protests. Perhaps the best known of these, the Mustapha Mahmoud protest camp, was organized by a group of Sudanese refugees in 2005. To date, it is recalled as one of the largest public protests in the history of independent Egypt (Moulin and Nyers 2007). It saw more than 3,000 refugees camping and protesting for over

\footnotetext{
${ }^{1}$ The account of Gutama's participation in the 2013 sit-in is based on secondary reports (Aljazeera 2013) and interviews with Oromo community leaders conducted in Cairo in January 2015 (author 2015).
} 
three months and led to a violent eviction suffered by the protesters, including the death of around thirty migrants. In spite of this, refugee protests in Cairo did not stop.

That the site for this contestation is a major city, not a camp located in a border zone, is consequential to asylum seekers' possibilities for political agency. As a growing body of literature on urban refugees has shown, the city can offer possibilities to political subjectivities that are not necessarily found in camps (e.g. Dryden-Peterson 2006; Fábos and Kibreab 2007; Darling 2011; Crisp et al. 2012). Darling (2016) outlines these possibilities in terms of 'politics of informality' and 'politics of presence', both of which refer to refugee's positioning in struggles for visibility as rights bearing subjects. He aptly notes that attention to these, often subtle, forms of politics "enables a valorization of incremental and often highly tactical practices that can constitute 'minor' political acts" (Darling 2016, 12). In a similar vein, Sanyal (2014) theorizes refugees' experiences of urban informality in the Global South - from sub-letting houses to reclaiming spaces through public protests - as "new politics" that emerge "through cracks in the system" of city governance (Sanyal 2014, 569).

An important setting for such refugee politics, Cairo is presently an urban conglomerate of some sixteen million people, over half of whom are estimated to live in informal areas (UNHCR 2015). Yet it is also home to one of the world's largest populations of 'urban refugees', which has grown significantly in recent years as a result of the Syrian crisis. The situation reflects Egypt's refugee policy that, with few exceptions, has avoided camps and favored autonomous settlement of forced migrants in the country's major cities. As we write, the population of concern of UNHCR Cairo amounts to 178,723 people, the majority of whom are Syrians (UNHCR 2016). This figure, however, does not include those who live in refugee-like conditions but choose not to register with the UN office. Actual numbers in Cairo are therefore possibly much higher. Syrians, Sudanese, Iraqis, Palestinians, Somalis, Ethiopians, and Eritreans are the largest communities in the Egyptian refugee population.

As in many other countries in the Middle East, the processing of asylum requests and the provision of humanitarian assistance are entirely delegated to the UNHCR "surrogate state" (Kagan 2012). In most cases, when asylum seekers arrive in Cairo and approach the local UNHCR office, an 'attestation paper' that certifies their registration and specifies a date for the refugee status determination interview is issued. It is oftentimes referred to as the 'white paper' by migrants. Unlike the 'yellow card' that identifies asylum seekers and the 'blue card' that provides a refugee status', it does not allow to apply for a regular residence permit nor to receive financial or medical assistance from UNHCR and its NGO partners. The only right the white paper establishes is the non-refoulement one, that is, the right not to be deported back to one's country. As the status determination interviews are usually issued no earlier than eighteen months after the initial registration, the new arrivals living in Cairo are de facto in a legal limbo in which their only option for getting by are self-reliance and informal community networks (Collyer et al. 2015).

\footnotetext{
${ }^{2}$ Currently in Egypt, the former is commonly issued to Syrian applicants due to the ongoing conflict in the country, but only exceptionally to other nationalities.
} 
Since the late 1990s, the UNHCR has been working on defining and applying an approach to the question of refugees living in urban areas. It rests upon two basic principles: First, expanding protection space beyond camps and thus recognizing the refugees who autonomously settle in cities as legitimately entitled to protection, and second, emphasizing the refugee populations' capacities for self-reliance and social and economic coping in the local urban environment (UNHCR 2005, 2011). Hence, settlement in Cairo both allows for and demands the active agency of asylum seekers. Upon coming to Cairo, they face expectations of self-reliance in the maintenance of their livelihood, while waiting for the agency to assess if they are vulnerable enough to receive help as refugees.

How do the hundreds of thousands of people seeking asylum in Cairo respond to these expectations? Coming from unlivable circumstances through exhausting journeys that often leave them in debt, and living in extremely precarious conditions with little formal status and often very limited social and economic resources, they should take care of themselves (and their families) for an unforeseen period of time, which usually means years rather than months. These subject positions, arising from the global refugee aid system, may seem unfeasible to fill. Yet the people who get through the system and receive asylum attest that this is not the case. In this article, we seek to understand these accomplishments as politics of performing refugeeness.

\section{The politics of performing refugeeness}

The pressures that migrants face when seeking asylum are well understood in the existing scholarship that discusses the performative aspects of refugeeness. For example, Roger Zetter (1991) has studied situations where asylum seekers are required to demonstrate that they qualify for the recognition of their refugee status. In one of the early accounts of refugeeness as an identity, he noted how those in need of assistance strive to be included and that this inclusion "required conformity; circumstances of 'story' had to be relinquished to the bureaucratic dictates of 'case'" (Zetter 1991, 47). In a similar vein, Trish Luker (2015) argues that even though in legal terms refugee status precedes its recognition, so that "a person is a refugee prior to legal determination procedures", it is the applicant's ability to perform refugeeness in the course of this status recognition that actually forms the refugee subject (Luker 2015, 92).

In analyzing the consequences of the need to perform refugeeness, some scholars have paid particular attention to the institutionally embedded scripting of what being a refugee entails and how this may label asylum seekers as certain kinds of human beings (e.g. Zetter 1991; 2007; Lippert 1999; Lacroix 2004). In this literature the question of refugeeness is understood and assessed from the point of view of asylum seekers' subjectivities molded by the demands set by the institutions and organizations that provide them vital assistance. As Zagor (2014) observes, such studies tend to view the refugee as a "site of governmentality, techniques for the production, discipline and domination of the subject" (Zagor 2014, 326). Others have sought to delineate the ways in which asylum seekers aim at persuading the authorities of the authenticity of their need for protection, and particularly the ways in 
which this "bureaucratic performance" comes to influence their narratives (e.g. Barsky 1994; Jeffers 2008). Here attention is often focused on the manner in which the pressured situation of refugee status determination tends to homogenize and flatten messy and complicated life situations into "a manageable set of narrative fragments" that fit the demands of the legal procedure (Macklin 2011, 137; see also Huysmans 2008; Bulley 2014).

Sympathetic toward the difficult circumstances in which refugeeness is performed, some research approaches have also highlighted asylum seekers' capacities to resist the discursive and institutional domains they encounter. In his editorial introduction to the newly established Journal of Refugee Studies, Roger Zetter (1988) captures the spirit well in pleading for a deeper understanding of "the ambiguous reactions which refugees frequently display towards assistance and settlement programmes - rigorous assertion of independence going hand in hand with dependency, indeed sometimes exploitation of the programmes for the political status and access which they ascribe" (Zetter 1988, 2-3).

Responding to this call, a scholarship has emerged with the intention to foreground the practices through which asylum seekers can mobilize agentic capacities and portray political activities (e.g. Puumala and Pehkonen 2010; Szczepanikova 2010). Some of this work focuses particularly on the politics of performance and how the actors involved in a refugee status determination may, each in their specific ways, seek to contribute to the outcome. For instance Jeffers (2008) has observed that asylum seekers aiming at a convincing and compelling narrative of persecution sometimes "are 'coached' by their legal advisors [...] in their performance of their victim's narrative for the courts" (Jeffers 2008, 218).

Judith Butler's (1993) work on performativity has been influential in much of this literature. Yet it has also been critiqued for neglecting the role of experience in performative agency and thus viewing the refugee subject as always already subjected by the forces of its constitution (Dyck and McLaren 2004; Zagor 2014). Rivetti's (2013) argument is an apt example of the latter as she posits that even the political claims that asylum seekers make "are performed through reiterated 'scripts of refugeeness', [and hence] do not reverse the 'grammar of domination' they went through" (Rivetti 2013, 306).

Scholars inspired by Ervin Goffman's (1959) ideas of performativity have employed an alternative reading of performative agency where intentionality plays a more significant role (e.g. Miller 2004; Yuval-Davis and Kaptani 2009; Fiddian-Qasmiyeh 2011). Whereas the Goffmanian distinction between 'front' and 'back' regions as the public and private frames of social life clearly has potential for grasping the asylum seekers' agentic capacities, it also runs the risk of neglecting the factors that constrain their autonomy and discursive control (Jeffrey 2013). Hence for instance Miller (2004) describes the refugee's control of interpersonal access to their lives as a largely voluntaristic movement between frontstage and backstage behaviors, and Behrman $(2014,267)$ describes sans-papiers' contestation over identity as a willful positing of "forms of subjectivity that can rupture the tropes of citizens and outsiders".

We build on the existing scholarship on the performative politics of refugeeness, but seek a more careful balance between elements that enable and curb the refugee subjects' 
autonomy as political agents. To this end we propose a reading of refugeeness not simply as a dominating identity structure, but rather as a form of subjectivity that operates on the possibility of experiencing a subjective distance between one's sense of self and the refugee identity proposed in encounters with institutional discourses and practices, such as those related to refugee status determination (Häkli and Kallio 2014). Rather than fixed positions, we consider refugee subjectivities to vary across different times, situations, and configurations. In exposing this plurality, we suggest that 'becoming refugee' is one significant instance where people employ their mundane political agencies, both challenging and reproducing the complex socio-political and socio-material relations that constitute the refugee regime (Kallio and Häkli 2017).

Along with Engin Isin $(2012,108)$, we understand political subjectivity as a way of "becoming political through relating to oneself and others, [and as] a performative force that breaks habits or ways of doing things and throws the subject into uncertainty, indeterminacy and the unknown". Yet we depart from his vocabulary that equates performativity with "repetition and iteration of forms, repertoires and descriptions under which political subjectivity is produced" (Isin 2012, 126). We argue that it is precisely the performative aspect of refugeeness that, paradoxically, enables asylum seekers not to become subjected refugee-subjects compelled to 'bare life'. Key here is the way in which performative action sustains a critical distance between the subject and the figure of the refugee that the situation proposes. To the extent that asylum seekers become attentive to the need to perform in specific ways - for instance the need to employ certain narratives concerning the reasons for their flight or specific details on their trajectories to Cairo - they may experience the refugee identity as an imposition and refrain from internalizing it, thus gaining intuitive or tactical (political) capacities (Denov and Bryan 2012; Bhimji 2015).

This heightened attentiveness towards the figure of the refugee, we argue, lies at the root of performative refugeeness, which provides asylum seekers opportunities to meaningful identity building and political agency in circumstances that they can do little about. We share Isin's (2012) conception of political becoming as purposive "because bodies sense the subject position they are taking up but are neither able to calculate nor predict its outcomes" (Isin 2012, 128). In discussing refugeeness as a performance, we do not subscribe to an individualistic or a 'substantialist' conception of subjecthood and agency because "'subjects' do not already exist prior to acts; the performance of acts through actions bring them into being" (Isin 2012, 129; see also Isin 2009; Zanotti 2013; Kallio 2016). On the contrary, we see subjectivity as a processual notion that highlights the relational and contextual constitution of the subject (Young 1990; Vacchelli 2011; Häkli 2013; Häkli and Kallio 2014; Baines 2015).

Moreover, the rise of attentiveness and awareness towards refugeeness is a social development, based on sharing experiences and knowledge between individuals and collectives, and on being and acting together in different situations where the figure of the refugee manifests itself in ways "individual yet collective, scripted yet experimental, unauthorized yet meaningful" (Isin 2012,120). Hence, even if subjectivity can be considered an inner dynamism of the human subject, political subjectivity constitutes contextually in the 
communities and societies where people lead their lives. In the next sections, we set out to trace from our interviews with asylum seekers indications of their attentiveness to the performative aspects of refugeeness, and read this as a possibility to (nascent) political agency.

\section{Studying refugeeness in Cairo}

The paper is based on the analysis of in-depth interviews and ethnographic observation carried out in Cairo in 2015, in the context of a wider research project on asylum seekers' migration in North-East Africa. The interviews included migrants from four different nationalities - Ethiopia, Eritrea, Syria and Sudan - who had recently arrived and started their asylum process in Cairo. The analyzed materials include twenty one interviews with asylum seekers, mostly individual but sometimes with two persons or a family, and five interviews with personnel working with aid agencies such as the International Organization for Migration (IOM) and refugee-led community-based organizations. Interviews with asylum seekers revolved around their journeys through Egypt and their current situation in Cairo, with particular attention paid to their relations with aid agencies.

This fieldwork period was preceded by a longstanding ethnographic research in Cairo (20112013), including participant observation with refugee families, community organizations, local and international NGOs and UN offices (Pascucci 2015; forthcoming). The analysis of the interviews is informed by this sustained engagement with the local context, as well as by our reflexive examination of the shifting roles occupied by researchers and informants throughout the research process. Yet, considering fieldwork encounters as 'embodied performances of negotiated subjectivities' (Dyck and McLaren 2004, 514; see also Szczepanikova, 2010), the situated positionalities we found ourselves in instigated few explicit articulations of refugeeness in the people we interviewed, thus adding to the methodological challenge of studying experiences empirically. Hence, to capture some of the unarticulated aspects of our encounters, we often recorded discrepancies, silences, frustration and grievances towards humanitarian actors. It is by reading our interviews in the light of these dissonances and 'fissures' that we seek to make sense of refugee performativity.

\section{Becoming attentive to the figure of the refugee}

With the idea of 'becoming refugee' we do not refer to a process whereby a person changes from one subjective state to another, developing refugeeness as a new complete identity. Rather, along with Isin (2012), we consider it as a state of political becoming where people gain awareness of refugeeness as an identity to relate to. While experienced in the present, such moments of attentiveness are strongly conditioned by people's (known) pasts in their home countries and what they imagine as (possible) future life opportunities provided by other states and NGOs. At the intersection of 'becoming refugee', their challenge is to convince the aid system that their past life entitles them to a refugee status. 
People start gaining awareness of refugeeness at the latest when they begin to consider leaving their countries of origin, and embarking on migration journeys that often are not straightforward. This attunement to refugeeness includes learning about other people's understandings and experiences regarding transportation, traveling routes and possible destinations, what they need on the way and upon arrival, and what aid they may expect to receive or be entitled to as asylum seekers and refugees. People may actively seek information about these things to plan their journey, or they may trust relatives and friends to organize the departure and the transitory settlement (Gilad 1990; Okeke Uzodike et al. 2012).

From these early steps, asylum seekers start building acquaintance with the figure of the refugee; the internationally protected subject as whom they may be recognized if granted the status (Dobson 2004). Let the journey of a Sudanese man provide an example of how attentiveness towards the figure of the refugee may evolve. We interviewed $\mathrm{Ahmad}^{3}$ in January 2015 in Cairo where he had arrived three months earlier. We learned that he was born in Darfur in the early 1980s, and having fled the Darfur War in 2003, had worked for years in different gold mines across Northern Sudan. However, mining turned out an uncertain source of livelihood, especially after the Sudanese government had taken control of the mines and the possibilities for 'freelance mining' diminished (interview 14). His earlier exposure to refugeeness was intensified by unfriendly encounters with the Sudanese authorities:

Ahmad: The government of Sudan harassed me many times. I was harassed by the police who wanted us to stop working in mining, and they arrested me and others when we tried to protest, I was beaten.

Interviewer: So you left Sudan for this.

Ahmad: Yes.

Interviewer: But did you want to come to Egypt, or did you have other possibilities?

Ahmad: To be honest, I was told that if you come to Cairo you can apply for asylum, so that's what I did.

Ahmad had learned from his friends about people in Port Sudan who could help him to get to Cairo. He took the trip with other individuals on the run, buying the services of smugglers operating in cooperation with border authorities. Upon arrival in Cairo, Ahmad met a Sudanese man who helped him arrange a temporary place to stay in the slum known as el Barageel, in Giza, and to register his case at the UNHCR office. There he was given the UNHCR proof of registration (the 'white paper'), which does not entitle him to any support, only permission to temporary residence in Cairo where his living conditions are very dire. As with thousands of other migrants, to improve his situation Ahmad has two options: To seek recognition as a refugee or leave Cairo. However, caught between pressures to seek asylum and secure a living, Ahmad was not really disposed to envision himself as a 'UNHCR refugee'.

\footnotetext{
${ }^{3}$ All names have been changed for anonymity and the interviews have been made with the aid of interpreter.
} 
Ahmad: They told me that this paper is useless. I went to CARITAS to try and get medical help and they told me this does not prove you are a refugee so we can't do anything for you, you just have to be here and wait.

Interviewer: I can see on your document that you have to wait for over two years for the refugee status determination interview.

Ahmad: Yeah, and at the moment I can't have a residence permit because this is not the yellow card, so CARITAS cannot help me.

Interviewer: What do you think you will do, will you wait for two years?

Ahmad: No. Really, I want to go back to Sudan and see my family.

Interviewer: Do you really want to go back?

Ahmad: How can one stay in this country if there are no jobs, and even the organizations who should provide you with help or assistance barely know that you are here.

Clearly, the situation in Cairo is in stark contrast with what Ahmad had expected. Yet, it is not the refugee status per se that Ahmad is considering to back away from, but rather the trying process of achieving it.

Ahmad: I know people who have been here for four years, five years without doing anything [... when] you came here, you approached an organization looking for protection [...] and they tell you that you have to wait for two years.

Besides waiting, the process entails performative adjustments of one's life to the expectations coming from the refugee status determination procedure. Some of these requirements are captured in our field notes from the day after Ahmad's interview:

When leaving the office Sadiq, our Sudanese interpreter, had met Ahmad and told him that while it is true that upon registration the UNHCR gives appointments after two years, there are things that can be done about that. Sadiq says that basically you have to advocate for yourself: you should attract NGO and UNHCR attention on your case, explaining repeatedly why you need help. In 2014, UNHCR had even instituted a telephonic hotline for people who are going through emergency situations. All these are channels one should use to get a faster processing for one's asylum case (field notes, interview 14).

Yet this advice may not have been what Ahmad was missing. Our discussion with him clearly indicates that he is not interpellated into the figure of the UNHCR refugee as his sense of self is rather attached to his role as a provider for his family.

Ahmad: They all depend on me. My family, my parents - I am the eldest son, I am supposed to help them, and I am here and I am not working, I am not getting any money. And my wife too - so I think I have to go back and look for another solution.

Interviewer: There are similar situations all over... 
Ahmad: Yeah, so what's the guarantee, what's the point of staying here? I am jobless, I have no job and no help that I can send to my family... There is no point in staying here.

Interviewer: What kind of help would you like at the moment?

Ahmad: I want a job, and I want money because I need to help my family, I need to send them money.

Interviewer: The UNHCR will not be able to help you?

Ahmad: Yeah [...] so I think I should take a final decision.

This is where fractures in Ahmad's 'refugeeness' are most explicit. To the point that he is struggling to sustain his familial identity, he is also aware of refugeeness as a proposed subject position that provides for him an alternative, while not particularly attractive, path forward. This attentiveness, essential to his political subjectivity, forms the core of his politics of (not) becoming refugee.

\section{Performing refugeeness}

For people hoping to settle into another country with little resources and no opportunity to migrate legally, becoming attentive towards the figure of the refugee is almost inevitable. It is well known among the asylum seekers in Cairo that only a fraction of the population may be granted the refugee status and even a smaller fraction gets resettled in a country where migrants have good life opportunities and possibilities to attain permanent residence. Many are well aware of the risks involved in being categorized as non-potential refugees and hence actively seek to prevent such positioning. The situation invites people to develop performative agencies by which to stand out as potential refugees and to get help while waiting.

A case in point among our research participants is Dirribe, an Ethiopian woman with Oromo nationality and a single mother with three children. Her trajectory towards Cairo had begun in 2005 when she and her husband left Ethiopia among thousands of others to work in Saudi Arabia, then continuing to Sudan where she had fled deportations from Saudi Arabia in 2013, to end in Cairo where she and her children had arrived in summer 2014 (interview 6). In talking about the journey, Dirribe explained why her husband was not with the family:

Interviewer: I imagine the Saudi Arabian deportations became a serious problem in 2013.

Dirribe: That's why we are here, basically. They did not regularize us and my husband was caught one day while working, and he was arrested.

Interviewer: Is he still there? Have you heard from him, or about him?

Dirribe: I don't know where he is. He might have been deported to Ethiopia or still in prison, if he got in trouble.

Dirribe's status as an asylum seeker is justified from the UNHCR perspective even though the family had not sought asylum when first escaping from Ethiopia. Yet she did not seem confident about her position as a person entitled to UNHCR support. While she had no 
reason to worry about our involvement in the matter, there was something in her disposition and body language that we ended up recording in our field notes.

Dirribe takes a deep breath and a short pause. She seems very uncomfortable with the last question, maybe because of sorrow and worry about her husband, or other personal problems. There might also be elements of her story that she is trying not to disclose, so as not to undermine her support from the UNHCR as a single mother (field notes, interview 6).

While keen on standing out as a UNHCR refugee for pragmatic reasons, we noticed that Dirribe was rather uncomfortable with having to portray refugeeness in herself. This became evident in the way she talked about her life in Cairo:

Interviewer: And how is your life here, how would you describe it?

Dirribe: Ah, I could talk about that forever, about how bad it feels. It's bad in a strange way, because when we first arrived, I was totally dependent on the family who was hosting me, totally, me and three kids. [...] I tried to make a living, to manage on my own, and I found a job [but] it was really very bad, I had to leave. Now I recently received the yellow card from UNHCR, and I get food help and my children go to school in Maadi.

Interviewer: I was thinking, it is still something better, it must have been hard to live in Saudi Arabia all these years with no documents?

Dirribe: In Saudi Arabia, you see, we were working. There you didn't have to worry when and where to find the next meal to give to your children as sometimes here [...] It wasn't a great life but at least you had that.

Besides her self-sustained life in Saudi Arabia, Dirribe had successfully navigated herself and her three children through some very difficult situations with smugglers during their journey to Cairo, which probably adds to her frustration of currently being largely dependent on external support (interview 6). Similar reservations towards the figure of the refugee, attesting to the fact that life could be otherwise, were expressed by many of our interviewees in personally varying ways. For some, like Ahmad and Dirribe, refugeeness appears an articulately contradictory identity, whereas for others the pressure to qualify as a potential refugee invited more performative figurations of refugeeness, showing confidence rather than unease when talking about themselves as vulnerable subjects.

This is the case with Kuma, a young Oromo man from Ethiopia. When asked about his background, he immediately knew how to address his past:

Interviewer: Can you tell me how your life was in Ethiopia?

Kuma: I left my country because of the continuous political persecution targeting my family, particularly my father, because of his links to local political groups. My father disappeared years ago, he was probably killed. This is why I left. I was only nine-to-ten-year-old when that happened to my father. After that, the government continued to harass my family, and I also had problems because of that, I was also persecuted (interview 10). 
Such an agonizing background is, of course, not uncommon among asylum seekers in Cairo. However, the formulaic manner in which Kuma recounted the focal events of his life suggests that there were performative elements present in his narrative (field notes, interview 10). Several of our interviewees had similar performative capacities with roots in previous experiences of applying for asylum - in Kuma's case, in Yemen in 2009. While we made our independence from the UNHCR refugee status determination process very clear to all participants, this is how we capture the performative disposition that characterized many of our interviews with people from East Africa:

Since one is expected to apply for asylum in the first country one arrives to, people feel compelled to explain that they did consider stopping [in Sudan] but then realized that it was not a safe option. This is something one finds in the interviews with Ethiopians and Eritreans: they all explain that there are campaigns of arrest and deportation in Sudan, and therefore they could not stay there (field notes, interview 20).

What seemingly are minor adjustments in personal narratives concerning travel to Cairo, actually reveal performative agencies based on attentiveness towards the figure of the UNHCR refugee. By bringing personal and collective pasts together with potential futures, we argue, these performative capacities enable people to relate with instead of simply collapsing into refugeeness.

\section{Raising awareness of inequalities and injustices}

The fractures in refugeeness exemplified in the previous sections are instances of attentiveness in which the empowering potential of refugeeness as a political subjectivity is vested. To mobilize this potential requires that experiences of such political subjectivity are articulated and shared through social encounters and interactions. It is their role in politicizing refugeeness that we now turn to.

The difficulties of getting by and getting help that our participants described to us entail various practices through which awareness about the inequalities and injustices embedded in the refugee aid system is raised and shared, both implicitly and explicitly. What our participants took up most frequently was the mismatch between their specific needs and the help that the aid agencies could provide them or the asylum seekers in general. They insisted that the UNHCR ought to respect basic human rights that pertain to all people. This argument is clearly based on shared awareness concerning the figure of the refugee and it is collectively articulated even if individually delivered. Consider, for example, the following three interview excerpts from our discussions concerning the assistance that the UNHCR is providing:

"Every week I go to the UNHCR office asking for their help, asking for their support and protection. But no one even talks to you there, no one cares." (Sudanese man, Interview 11). 
Wherever I go, they keep telling me that I will not get any medical assistance because of my paper. The white paper does not give you any right. But I need a doctor to heal the pain at my arm. [...] I tried to go to CARITAS, but they told me that with the paper I have, the white paper, they cannot give me any appointment, I cannot receive any assistance. It is very unjust. (Ethiopian man, interview 20).

The office that granted me protection on paper should take responsibility for who you are and take responsibility upon you. Here, UNHCR gives you asylum but they do not give you protection. Protection means access to health care, access to education and public health. (Eritrean man, interview 15).

Many asylum seekers have become articulately aware about the injustices of their shared situation in Cairo. Appealing to human rights, they contend that an international aid agency cannot treat people selectively according to the status of their applications, the progression of which is in the agency's own hands. Our interviewees frequently raised the problematic character of the white paper they had been given by the UNHCR upon registering, pointing out that it does not guarantee them basically any rights. Also the yellow and the blue card were mentioned in this light even though in principle these papers should provide asylum seekers with safety and support.

It is very hard to live here in Cairo, it is really difficult to stay here. This is why people are going to Libya and then to Europe via sea. Because the UNHCR cannot do anything for them, they are just giving them yellow cards or blue cards (Young Eritrean man, interview 13).

In urban settings like Cairo where asylum seekers live in the city with millions of other underprivileged people and where the state is hostile rather than supportive towards their presence, the figure of the refugee is openly paradoxical. On the one hand, asylum seekers are expected to be extremely vulnerable in their countries of origin, but on the other hand, they should be very proficient in their new environment. Understanding this is vital to people who wish to be recognized as refugees in Cairo, not only to fit in with the aid system, but also to survive in the highly precarious circumstances.

Yet, as Darling $(2016,14)$ argues, cities may foster "political solidarities centered on common experiences of the urban across otherwise distanciated constituencies" and thus help shift our attention away from the urban context as merely a site for governing mobility, towards its role as providing opportunities for refugee politics and subjectivity. By becoming attentive to the figure of the refugee through encounters with others with experience and knowledge about the refugee aid system, and by sharing their feelings and understandings about the inequalities and injustices embedded in their precarious life situations, awareness may be raised and potential to dissenting agency enhanced among the asylum seekers in Cairo. This may take articulated forms and unfold through organized activities like requests for medical help, sit-ins, and open protests - acts that Moulin and Nyers (2007) refer to as participation in the "global political society" by those excluded from the more established political orders (cf. Isin 2009 on the sans-papiers). However, such awareness raising may also 
occur as part of everyday activities where asylum seekers meet each other and get connected in seeking for housing, food, health care, electricity, internet access, and other basic supplies and services (for analyses on everyday politics in Cairo, see Pascucci 2015; 2016; forthcoming).

Some people are engaged in both kinds of political agencies, like Abdul, a young Sudanese Masalit man with a long history of asylum seeking in different countries. He is actively helping other asylum seekers in very mundane ways though a community center that he has established with others like him:

I have seen how much difference it can make that there are people there to help. So now what I am interested in is that I can also help, help other people who are in critical situations, in any ways. At least I can do something with these negative experiences I had [...] (interview 9).

However, his growing awareness of the inequalities embedded in the refugee aid system has also led him to join in and organize public demonstrations:

The UNHCR is a very controversial organization because, in theory, they are an international humanitarian organization, but then all those things happen and you wonder. For instance, we are from Darfur right? The conflict in our land has lasted much longer, and it is much more violent, and people are poorer, than in the cases of Iraq or Syria. But then here [...] the quantity and quality of the assistance they receive is not even comparable to that of African refugees. Why? Aren't we supposed to be all the same as human beings? What is the difference between African and Iraqi or Syrian people? I am very sorry to say that [...] it is not an international humanitarian organization. It is a racist organization (interview 9).

Importantly, the sharing and awareness raising that derives from people's political subjectivities does not require that people align with each other ideologically or that they come from the same region or have similar socio-economic backgrounds. Quite obviously, asylum seekers' ways of life and orientations in Cairo vary notably, and they even have opposing views on what should be done in the current situation. We suggest that their connectedness is enabled most importantly by subjectivities through which they relate to the figure of the UNHCR refugee from their personal starting points. By performing refugeeness through these active position takings, they may retain their sense of self as particular persons and develop an understanding about their shared grievances. Connecting through these experiences does not require a shared language or overt communication as it unfolds primarily affectively, following the logic of connective rather than collective political formation (Bennett and Segerberg, 2012). This means that while asylum seekers may share attentiveness and awareness with each other, they may come to act politically in differing ways.

\section{Conclusion: mobilizing refugeeness}


All asylum seekers who wish to be recognized as potential receivers of refugee status need to perform refugeeness to a greater or lesser extent because at stake for them is to be identified as in need of international protection. Our engagement with asylum seekers in Cairo shows that elements of this intuitive or intentional performativity include specific ways of articulating political persecution and unbearable situations in the country of origin, hardships of smuggling and trafficking during the travel, severe vulnerability related to securing livelihoods in Cairo, and the lack of medical assistance, basic supplies, or economic support while waiting for the refugee status determination.

However, we want to make it very clear that performing refugeeness is hardly ever about egocentric strategies played out to mislead aid organizations or to exploit the global refugee aid system to serve one's own ends. Rather, it is about the empowering distance between one's sense of self and the identity of the refugee forcefully proposed to the asylum seekers to adopt and adjust to. Essentially, it is also about retaining humanity in circumstances that are oppressive and humiliating as people are expected to have their lives at stake in a struggle where survival is the only acceptable horizon of hope.

In this paper we have analyzed political subjectivities related to 'becoming refugee'. We propose that by conceiving refugeeness as a performed identity we can attune to the ways in which people even in most dire circumstances are able to avoid total subordination that the internalization of the figure of the refugee could mean. With the capacity to distance themselves from the identity of refugee, the people who seek asylum in Cairo also sustain a political subjectivity that, as an empowering potential, may translate into awareness and even activism.

Indeed, while the politics of performing refugeeness is often practiced individually, it may form an important starting point to many collective activities that people living in precarious conditions engage with. The most visible forms of performed refugeeness take place in sitins and other gatherings, and in resistant movements where asylum seekers set out to openly criticize and challenge the international refugee aid system. In practice, these typically address the UNHCR as its representative in Cairo. The arguments made in protests usually point to the impossibility of fulfilling the requirements set to asylum seekers, and not to the UNHCR requests as such, which shelters the protesters as potential refugees. They do not argue that people waiting for the interviews and decisions should not care for themselves, but ask that their self-reliance ought to be made possible. Neither do they argue against vulnerability as the criteria of refugee status; instead, they request that their vulnerability is noticed as an ongoing situation. The protesters are, therefore, concurrently agreeing on the 'UNHCR refugee' as a legitimate category yet noticing that they are not provided equal opportunities to fulfill that.

As experiences of refugeeness get not only shared but also articulated, they may be connected with different agendas and openly politicized. Usually there are organized actors leading these protests, like the Oromo community in Cairo, but they cannot mobilize the events alone. The "multitudes" or "crowds" who share similar concerns, as portrayed by Zevnik (2015), are needed for the emergence of organizationally enabled networks of connective action, as identified in Bennett and Segerberg's $(2012,756)$ typologies of 
collective and connective action networks. These include people who are willing to join in sit-ins to imply that people need to be helped without taking strong stances toward any real politics, and those who do not wish to take part in any public activities yet provide support to the protesters at the background.

Obviously, the politics of asylum seeking do not end when people succeed to leave places like Cairo because the political subjectivities they have developed through refugee journeys remain influential when people seek to settle in their new communities, and claiming for their rights and status in the states of residence (Ilcan and Rygiel 2015; Bhibji 2015). Sharing an understanding about, and a forced relation to, the paradoxical figure of the refugee, we argue, is a major factor in the emergence of these political formations. The asylum seekers who are deemed to perform this figure, while trying to survive in and save themselves from the precarious life situations where they find themselves, are at the root of the individual, connective, and collective political agencies at play in Cairo and beyond.

\section{Acknowledgements}

We wish to thank the editors of IPS and the anonymous referees for their engaged and helpful comments and suggestions. We are also grateful to the Academy of Finland Centre of Excellence in Research on the Relational and Territorial politics of Bordering, Identities and Transnationalization (RELATE, grant SA272168), and the Space and Political Agency Research Group (SPARG) at the University of Tampere for an inspiring research environment.

\section{References}

ABERMAN, TANYA. (2014) Gendered Perspectives on Refugee Determination in Canada. Refuge: Canada's Journal on Refugees 30 (2): 57-66.

ACHCAR, GILBERT. (2013) The People Want: A Radical Exploration of the Arab Uprising. Los Angeles: University of California Press.

AGAMBEN, GIORGIO. (1998) Homo Sacer. Sovereign Power and Bare Life. Stanford, CA: Stanford University Press.

AL JAZEERA. (2013) Ethiopian Refugees: Persecuted Oromo Demand UN Protection in Egypt Amid Dam Dispute. Available at http://www.aljazeera.com/indepth/inpictures/2013/06/201361711365644208.html (Accessed October 2, 2015.)

BAINES, ERIN. K. (2015) "Today, I Want to Speak Out the Truth": Victim Agency, Responsibility, and Transitional Justice. International Political Sociology 9 (4): 316-32.

BARSKY, ROBERT F. (1994) Constructing a Productive Other: Discourse Theory and the Convention Refugee Hearing. Philadelphia: John Benjamins Publishing. 
BAYAT, ASEF. (2010) Life as Politics. How Ordinary People Change the Middle East. Amsterdam: Amsterdam University Press.

BEHRMAN, SIMON (2014) Accidents, Agency and Asylum: Constructing the Refugee Subject. Law and Critique 25 (3): 249-70.

BENNETT, W. LANCE AND SEGERBERG, ALEXANDRA. (2012) The Logic of Connective Action: Digital Media and the Personalization of Contentious Politics. Information, Communication \& Society 15 (5): 739-68.

BHIMJI, FAZILA. (2015) Collaborations and Performative Agency in Refugee Theater in Germany. Journal of Immigrant \& Refugee Studies, DOI: 10.1080/15562948.2015.1024813

BULLEY, DAN. (2014) Inside the Tent: Community and Government in Refugee Camps. Security Dialogue 45 (1): 63-80.

BUSH, RAY AND AYEB, HABIB. (2012) Marginalities and Exclusion in Egypt. London: Zed Books.

BUTLER, JUDITH (2011) Bodies that Matter: On the Discursive Limits of "Sex". London: Routledge.

COLLYER, MICHAEL, AHMED, BASHAIR, BREINES, MARKUS, IARIA, VANESSA AND PASCUCCI, ELISA. (2015) Beyond Root Causes: Fragmented Migration in the Middle East and North Africa. Migration Policy Practice 5 (3): 14-19.

CRISP JEFF, MORRIS TIM AND REFSTIE HILDE. (2012) Displacement in urban areas: New challenges, new partnerships. Disasters 36 (S1): S23-S42.

DARLING, JONATHAN. (2009) Becoming Bare Life: Asylum, Hospitality, and the Politics of Encampment. Environment and Planning D: Society and Space 27 (4): 649-65.

DARLING, JONATHAN. (2011) Giving space: Care, generosity and belonging in a UK asylum drop-in centre. Geoforum 42(4): 408-17.

DARLING, JONATHAN. (2014) Asylum and the Post-Political: Domopolitics, Depoliticisation and Acts of Citizenship. Antipode 46(1): 72-91.

DARLING, JONATHAN. (2016) Forced migration and the city: Irregularity, informality and the politics of presence. Progress in Human Geography (early view)

doi:10.1177/0309132516629004

DENOV, MYRIAM AND BRYAN, CATHERINE. (2012) Tactical Maneuvering and Calculated Risks: Independent Child Migrants and the Complex Terrain of Flight. New Directions for Child and Adolescent Development, 2012 (136): 13-27.

DIKEN, BULENT AND LAUSTSEN, CARSTEN B. (2005) The Culture of Exception: Sociology Facing the Camp. London: Routledge.

DOBSON, STEPHEN. (2004) Cultures of Exile and the Experience of Refugeeness. Bern: Peter Lang. 
DRYDEN-PETERSON SARAH. (2006) 'I find myself as someone who is in the forest': Urban refugees as agents of social change in Kampala, Uganda. Journal of Refugee Studies 19 (3): 381-95.

DYCK, ISABEL AND MCLAREN, ARLENE TIGAR. (2004) Telling It like It Is? Constructing Accounts of Settlement with Immigrant and Refugee Women in Canada. Gender, Place \& Culture 11 (4): 513-34.

EDKINS, JENNY. (2000) Sovereign Power, Zones of Indistinction, and the Camp. Alternatives: Global, Local, Political 25 (1): 3-26.

FÁBOS ANITA AND KIBREAB GAIM. (2007) Urban refugees: Introduction. Refuge 24 (1): 3-10. FIDDIAN-QASMIYEH, ELENA. (2011) The Pragmatics of Performance: Putting 'Faith' in Aid in the Sahrawi Refugee Camps. Journal of Refugee Studies 24 (3): 533--47.

FRASER, NANCY. (2000) Rethinking Recognition. New Left Review 3 (May-June): 107-120.

GASS, ANYA. (2014) Becoming the 'Refugee' - Creation of a Gendered Subjectivity among Male Asylum Seekers in Switzerland. Tijdschrift voor Genderstudies 17 (2): 115-29.

GILAD, LISA. (1990) The Northern Route: An Ethnography of Refugee Experiences. St John's: ISER Books.

GILL, NICK. (2010) New State-Theoretic Approaches to Asylum and Refugee Geographies. Progress in Human Geography 34 (5): 626-45.

GOFFMAN, ERVING. (1959). The Presentation of Self in Everyday Life. New York: Doubleday. GRABSKA, KATARZYNA. (2006) Marginalization in Urban Spaces of the Global South: Urban Refugees in Cairo. Journal of Refugee Studies 19 (3): 287-307.

HÄKLI, JOUNI. (2013) State space - outlining a field theoretical approach. Geopolitics 18 (2): 343-55.

HÄKLI, JOUNI AND KALLIO, KIRSI PAULIINA. (2014) Subject, action and polis: Theorizing political agency. Progress in Human Geography, 38 (2): 181-200.

HAMOOD, SARA. (2006) African Transit Migration through Libya to Europe: The Human Cost. American University in Cairo, Forced Migration and Refugee Studies.

HODGE, PAUL. (2015) A Grievable Life? The Criminalisation and Securing of Asylum Seeker Bodies in the 'Violent Frames' of Australia's Operation Sovereign Borders. Geoforum 58: 122-31.

HUYSMANS, JEF. (2008) The Jargon of Exception-On Schmitt, Agamben and the Absence of Political Society. International Political Sociology 2 (2): 165-83.

ILCAN, SUZAN AND RYGIEL, KIM. (2015) Resiliency Humanitarianism: Responsabilizing Refugees through Humanitarian Emergency Governance in the Camp. International Political Sociology 9 (4): 333-51. 
ISIN, ENGIN. (2009) Citizenship in flux: The figure of the activist citizen. Subjectivity 29 (1): 367-88.

ISIN, ENGIN. (2012) Citizens without frontiers. London: Continuum.

JAMES, PAUL. (2014) Faces of Globalization and the Borders of States: From Asylum Seekers to Citizens. Citizenship Studies 18 (2): 208-23.

JEFFERS, ALISON. (2008) Dirty Truth: Personal Narrative, Victimhood and Participatory Theatre Work with People Seeking Asylum. Research in Drama Education: The Journal of Applied Theatre and Performance 13 (2): 217-21.

JEFFREY, ALEX. (2013). The Improvised State: Sovereignty, Performance and Agency in Dayton Bosnia. Chichester: John Wiley \& Sons.

KAGAN, MICHAEL. (2012) The UN 'Surrogate State' and the Foundation of Refugee Policy in the Middle East. Scholarly Works. Paper 781. Available at http://scholars.law.unlv.edu/facpub/781 (Accessed December 18, 2015.)

KALLIO, KIRSI PAULIINA (2016) Shaping Subjects in Everyday Encounters: Intergenerational Recognition in Intersubjective Socialisation. Environment and Planning D: Society and Space. (early view). doi:10.1177/0263775816654916

KALLIO, KIRSI PAULIINA AND HÄKLI, JOUNI. (2017) Geosocial Lives in Topological Polis: Mohamed Bouazizi as a Political Agent. Geopolitics 22 (1) (early view). doi:10.1080/14650045.2016.1208654

LACROIX, MARIE. (2004) Canadian Refugee Policy and the Social Construction of the Refugee Claimant Subjectivity: Understanding Refugeeness. Journal of Refugee Studies 17 (2): 14766.

LATIF, NADIA. (2008) Making refugees. CR: The New Centennial Review 8 (2): 253-72.

LIPPERT, RANDY. (1999) Governing Refugees: The Relevance of Governmentality to Understanding the International Refugee Regime. Alternatives 24 (3): 295-328.

LUKER, TRISH. (2015) Performance Anxieties: Interpellation of the Refugee Subject in Law. Canadian Journal of Law and Society 30 (1): 91-107.

MACKLIN, AUDREY. (2011) Refugee Roulette in the Canadian Casino. In Refugee Roulette: Disparities in Asylum Adjudication and Proposals for Reform, edited by Jaya Ramji-Nogales, Andrew I. Schoenholtz and Philip G. Schrag, 135-63. New York: New York University Press.

MALKKI, LIISA H. (1992) National geographic: the rooting of peoples and the territorialization of national identity among scholars and refugees. Cultural anthropology 7(1): 24-44.

MALKKI, LIISA H. (1995) Refugees and Exile: From "Refugee Studies" to the National Order of Things. Annual Review of Anthropology, 24: 495-523.

MCNAY, LOIS (2014). The misguided search for the political. Cambridge: Polity Press. 
MILLER, KENNETH E. (2004). Beyond the Frontstage: Trust, Access, and the Relational Context in Research with Refugee Communities. American Journal of Community Psychology, 33 (3-4): 217--27.

MOULIN, CAROLINA AND NYERS, PETER. (2007) "We Live in a Country of UNHCR" - Refugee Protests and Global Political Society. International Political Sociology 1 (4): 356-72.

NYERS, PETER. (1998) Refugees, Humanitarian Emergencies, and the Politicization of Life. Refuge: Canada's Journal on Refugees 17 (6): 16-21.

NYERS, PETER. (2006) Rethinking Refugees: Beyond States of Emergency. New York: Routledge.

OKEKE UZODIKE, UFO, IDONIBOYE-OBU, SAKIEMI A., \& WHETHO, AYO. (2012) 'Forced to Flee': Conflicts and Mobilities in Africa's Great Lakes Region. Alternation: Interdisciplinary Journal for the Study of the Arts and Humanities in Southern Africa 19 (1): 173-98.

OLIVIUS, ELISABETH. (2014) (Un) Governable Subjects: The Limits of Refugee Participation in the Promotion of Gender Equality in Humanitarian Aid. Journal of Refugee Studies 27 (1): 4261.

ONG, AlHWA. (2003) Buddha is Hiding: Refugees, Citizenship, the New America. Berkeley: University of California Press.

OWENS, PATRICIA. (2012) Human Security and the Rise of the Social. Review of International Studies, 38 (3): 547-67.

PASCUCCI, ELISA. (2015) Diaspora, Immobility and the Everyday Politics of Waiting: Young Iraqi Refugees in Cairo. In Diasporas of the Modern Middle East: Contextualising Community, edited by Anthony Gorman and Sossie Kasbarian, 338-69. Edinburgh, UK: Edinburgh University Press.

PASCUCCI, ELISA. (forthcoming) From 'refugee population' to political community: the Mustapha Mahmoud refugee protest camp (Cairo, Egypt, September-December 2005). In Protest Camps in International Context: Spaces, Infrastructures, and Media of Resistance, edited by Gavin Brown, Anna Feigenbaum, Fabian Frenzel and Patrick McCurdy. Bristol: Policy Press at the University of Bristol.

PASCUCCI, ELISA. (2016) Transnational disruptions: materialities and temporalities of transnational citizenship among Somali refugees in Cairo. Global Networks, 16 (3): 326-43.

PUUMALA, EEVA AND PEHKONEN, SAMU. (2010) Corporeal Choreographies between Politics and the Political: failed asylum seekers moving from body politics to bodyspaces. International Political Sociology 4 (1): 50-65.

RIVETTI, PAOLA. (2013) Empowerment without Emancipation Performativity and Political Activism among Iranian Refugees in Italy and Turkey. Alternatives 38 (4): 305-20.

ROSSDALE, CHRIS. (2015) Occupying Subjectivity: Being and Becoming Radical in the TwentyFirst Century: Introduction. Globalizations 12 (1): 1-5. 
SANYAL, ROMOLA. (2014) Urbanizing Refuge: Interrogating Spaces of Displacement. International Journal of Urban and Regional Research 38 (2): 558-72.

SOGUK, NEVZAT. (1999) States and Strangers. Refugees and Displacements of Statecraft. Minneapolis: University of Minnesota Press.

SZCZEPANIKOVA, ALICE. (2010) Performing Refugeeness in the Czech Republic: Gendered Depoliticisation through NGO Assistance. Gender, Place and Culture 17 (4): 461-77.

TYLER, IMOGEN AND MARCINIAK, KATARZYNA. (2013) Immigrant Protest: An Introduction. Citizenship Studies 17 (2): 143-56.

UNHCR. (2005) Handbook for Self-reliance. Available at http://www.unhcr.org/44bf7b012.pdf (Accessed December 7, 2015.)

UNHCR. (2010) Convention and protocol relating to the status of refugees. Available at http://www.unhcr.org/3b66c2aa10.html (Accessed September 21, 2015.)

UNHCR. (2011) Promoting Livelihoods and Self-reliance. Operational Guidance on Refugee Protection and Solutions in Urban Areas. Available at http://www.unhcr.org/4eeb19f49.pdf (Accessed December 7, 2015.)

UNHCR. (2015) 2015 UNHCR Country operations profile - Egypt. Available at http://www.unhcr.org/cgi-bin/texis/vtx/page?page=49e486356 (Accessed January 7, 2016.)

UNHCR. (2016) Egypt UNHCR Operational Updated 2016. Available at http://www.unhcr.org/protection/operations/5548c50f9/egypt-unhcr-operationalupdate.html?query=Egypt (Accessed May 23, 2016.)

VACCHELLI, ELENA. (2011) Geographies of subjectivity: locating feminist political subjects in Milan. Gender, Place \& Culture 18(6): 768-785.

WALTERS, WILLIAM. (2008) Acts of Demonstration: Mapping the Territory of (Non)Citizenship. In Acts of Citizenship, edited by Engin Isin and Greg Marc Neilson, 182-206. London: Zed Books.

YOUNG, IRIS MARION. (1990) Justice and the Politics of Difference. Princeton, NJ: Princeton University Press.

YUVAL-DAVIS, NIRA AND KAPTANI, ERENE. (2009). Performing identities: Participatory theatre among refugees. In Wetherell, Margaret (ed.). Theorizing Identities and Social Action, edited by Margaret Wetherell, 56-74. Available at

http://link.springer.com/chapter/10.1057/9780230246942_4 (Accessed: 21 December 21, 2015.)

YUVAL-DAVIS, NIRA. (2013) Citizenship, Autochthony, and the Question of Forced Migration. Refugee Survey Quarterly 32 (2): 53-65. 
ZAGOR, MATTHEW. (2014) Recognition and narrative identities: is refugee law redeemable? In Fiona Jenkins, Mark Nolan and Kim Rubenstein (eds). Allegiance and Identity in a Globalised World. Cambridge: Cambridge University Press.

ZANOTTI, LAURA. (2013) Governmentality, Ontology, Methodology: Re-thinking Political Agency in the Global World. Alternatives: Global, Local, Political November 38 (4), 288-304. ZETTER, ROGER. (1988) Refugees and Refugee Studies - A label and an Agenda. Journal of Refugee Studies 1 (1): 1-6.

ZETTER, ROGER. (1991) Labelling Refugees: Forming and Transforming a Bureaucractic Identity. Journal of Refugee Studies 4 (1): 39-62.

ZEVNIK, ANDREJA. (2015) Maze of Resistance: Crowd, Space and the Politics of Resisting Subjectivity. Globalizations 12 (1): 101-15. 